\title{
The Importance of Enrichment Factor (EF) and Geoaccumulation Index (Igeo) to Evaluate the Soil Contamination
}

\section{Maurizio Barbieri*}

Department of Earth Science, Sapienza University of Rome, P.le Aldo Moro 5 - 00185 Rome, Italy

${ }^{*}$ Corresponding author: Prof. Maurizio Barbieri, Department of Earth Science, Sapienza University of Rome, P.le Aldo Moro 5 - 00185 Rome, Italy, Tel: +39-0649914593; E-mail: maurizio.barbieri@uniroma1.it

Received date: Dec 15, 2015; Accepted date: Jan 05, 2016; Publised date: Jan 10, 2016

Copyright: ( 2016 Barbieri M. This is an open-access article distributed under the terms of the Creative Commons Attribution License, which permits unrestricted use, distribution, and reproduction in any medium, provided the original author and source are credited.

\begin{abstract}
Heavy metals are natural constituents of soils and their concentration varies depending on parental materials. In the last years, the content of heavy metal in soils has increased due to human activities as: distribution of fertilizers, pesticides, industries, waste disposal and air pollution. Due to these activities the life capacity of soils decreased; especially where the natural background is already high because of natural parental material richness in heavy metal. As a matter of fact it is very important to distinguish between the natural background values and anthropogenic inputs, and to understand that the background values change from area to area and with the scale of the area investigated. There is currently a wide variety of methods used to evaluate soil contamination. To evaluate the soil contamination rate different indexes like Enrichment Factor (EF) and geoaccumulation index (Igeo) can be applied. These indexes are used to assess the presence and intensity of anthropogenic contaminant deposition on surface soil.
\end{abstract}

Keywords: Enrichment factor; Geoaccumulation index; Soil

\section{Introduction}

Soil is the preeminent source of most biologically active trace elements such as Lead, Cadmium, Chromium, Nickel, Silver, and Zinc that reach man through plants and animals [1]. The trace element content of soil depends on the nature of its parent rocks and also the amount of sewage sludges, industrial wastes and fertilizer impurities entering the soil [2]. Although fewer than 20 trace elements are required for the health growth of plants and animals, the excess concentration of these might be phytotoxic and may have adverse effects on animal health $[1,3,4]$. Extensive studies have been conducted to obtain data on the trace elements in soils from varieties of environments throughout the world, including industrialized cities, highway road sides rural areas in old mining regions and agricultural land used for crops or grazing [5-12]. It is generally known that rivers and related urban environments have been severely contaminated with metals (eg. $\mathrm{Cd}, \mathrm{Cu}, \mathrm{Pb}$ and $\mathrm{Zn}$ ) as a result of historic and modern mining and industrial operations [13-15]. The release of such contaminants can pose a significant potential environmental and human health threat to people living around such environments [15]. The presence of metals, at concentrations above certain thresholds, affects the microbiological balance of soils, and can decrease their fertility. Soil pollution due to heavy metals contamination is a serious problem as there are toxic and their bio-accumulation capacity is very dangerous for its effects on food chain. Heavy metals occur naturally in the soil environment from the pedogenetic processes of weathering of parent materials at levels that are regarded as trace $(<1000 \mathrm{mg} / \mathrm{kg})$ and rarely toxic [16]. Due to the human activities most soils as of industrial, as of rural and urban environments may accumulate one or more heavy metals. Many metals, such as $\mathrm{Cu}$ and Se, are essential elements for growth plant and for living organism, but high concentrations of these elements become toxic. Industrialization, urbanization and agricultural practices are the three main sources of metals in soils. Heavy metals in the soil from anthropogenic sources tend to be more mobile, hence bio-available than pedogenic or lithogenic ones $[17,18]$. Metal-bearing soils in contaminated sites can originate from a wide variety of anthropogenic activities in the form of metal mine tailings, disposal of high metal wastes in improperly protected landfills, leaded gasoline and lead-based paints, land application of fertilizer, animal manures, biosolids (sewage sludge), compost, pesticides, coal combustion residues, petrochemicals, and atmospheric deposition [16]. It is estimated that the contribution of metals from anthropogenic sources in soils is higher than the contribution from natural ones [19]. Many authors observed significant increases in soil metal content not only in areas of high industrial activity but also in areas far from industrial centres, due to long-range atmospheric transport [20,21]. The assessment of metal contamination is most important for the human survival. The only determination of the rates of metals in the surface horizons of the soil cannot provide extensive indications about the state of contamination of soils. This kind of information does not allow the distinction between natural background and anthropogenic enrichment. Furthermore it must be evaluated the possible relationship with the characteristics of the substrate (parental material), and the use of the soil. The natural content of heavy metals can vary in a large range depending on the material of which the soil has made of. Very important is the difference between background values and baseline values:

Background values: Natural contents of substance in the soil completely dependent on the compositional and mineralogical characteristic of the parent/source geological material;

Baseline values. Actual mostly diffuse range of concentration of an given element in a specific area dependent both on the nature of the parent geological/source material and on the historic diffuse release 
into the environment of contaminants from anthropogenic sources [22].

There are different indexes generally used to identify metal concentrations of environmental concern like: the metal enrichment factor (EF) and geoaccumulation indexes (Igeo) [23,24]. These indexes identify, numerically, pollution level soils and normally they are calculated on the soil exchangeable fraction because it represents the real bio-available fraction. This fraction is obtained by applying the first step of Tessier [25] procedure and optimised by Frankowsky et al. [26]. The bio-available metal content in soil exerts a decisive impact on soil quality and it's used in food production. Hence, the assessment of metal contamination is of vital importance in farming areas.

\section{Enrichement Factor (EF) and Geoaccumulation Index (Igeo)}

The Enrichment Factor (EF) in metals and Geoaccumulation Index (Igeo) (Eq. 1 and 2) are indicators used to assess the presence and intensity of anthropogenic contaminant deposition on surface soil. These indexes of potential contamination are calculated by the normalization of one metal concentration in the topsoil respect to the concentration of a reference element. A reference element is an element particularly stable in the soil, which is characterized by absence of vertical mobility and/or degradation phenomena. The constituent chosen should also be associated with finer particles (related to grain size), and its concentration should not be anthropogenically altered [27]. Typical elements used in many studies are $\mathrm{Al}, \mathrm{Fe}, \mathrm{Mn}$ and $\mathrm{Rb}$, and also total organic carbon and grain size are among those most used [27-30]. Aluminium is a conservative element and a major constituent of clay minerals, and it has been used successfully by several scientists [31-33].

Fe has been used by many authors working on marine and estuarine sediments [34,35].

But Iron is not a matrix element and its geochemistry is similar to that of many traces elements in oxic and anoxic environment [36]. For many years the background values used were Earth crust and soil values $[37,38]$.

Some authors suggest that element concentrations measured in a deeper soil horizon (subsoil) can be considered a "local background" for the upper soil horizons [39,40].

The Enrichment Factor is expressed as follow:

$$
\text { (1) } \mathrm{EF}=(\mathrm{Metal} / \mathrm{RE})_{\text {soil }} /(\mathrm{Metal} / \mathrm{RE})_{\text {background }}
$$

Where, RE is the value of metal, adopted as Reference Element. The numerical results are indicative of different pollution level. Values of $0.5 \leq \mathrm{EF} \leq 1.5$ suggest that the trace metal concentration may come entirely from natural weathering processes [41]. However, an EF>1.5 indicates that a significant portion of the trace metals was delivered from non-crustal materials so, these trace metals were delivered by other sources, like point and non-point pollution and biota [41-43,39]. With EF index, soil quality state can be indicate by different classes (Table 1) range from $\mathrm{EF}<2$ (Deficiency to minimal enrichment) to $\mathrm{EF}>40$ (Extremely high enrichment) [42].

The Geoaccumulation Index (Igeo) was originally defined by Müller [44] for metal concentrations in the 2-micron fraction and was developed or global standard shale values. This index is expressed as follows:

\section{(2) Igeo $=\ln \mathrm{Cn} / 1.5^{\star} \mathrm{Bn}$}

$\mathrm{Cn}$ is the measured concentration of the element in soil dust, $\mathrm{Bn}$ is the geochemical background value and the constant 1.5 allows us to analyze natural fluctuations in the content of a given substance in the environment and to detect very small anthropogenic influence. Müller [45] has defined seven classes of Geoaccumulation Index (Table 2) ranging from Class 0 (Igeo $=0$, unpolluted) to Class 6 (Igeo $>5$, extremely polluted). The highest class (Class 6) reflects at least a 100fold enrichment factor above background values.

\begin{tabular}{|l|l|}
\hline Value & Soil dust quality \\
\hline$E F<2$ & Deficiency to minimal enrichment \\
\hline $2<E F<5$ & Moderate enrichment \\
\hline $5<E F<20$ & Significant enrichment \\
\hline $20<E F<40$ & Very high enrichment \\
\hline$E F>40$ & Extremaly high enrichment \\
\hline
\end{tabular}

Table 1: EF categories.

\begin{tabular}{|l|l|l|}
\hline Class & Value & Soil dust quality \\
\hline 0 & Igeo $\leq 0$ & Uncontaminated \\
\hline 1 & $0<$ Igeo $<1$ & Uncontaminated to moderatelly contaminated \\
\hline 2 & $1<$ Igeo $<2$ & Moderately contaminated \\
\hline 3 & $2<$ Igeo $<3$ & Moderately to heavily contaminated \\
\hline 4 & $3<$ Igeo $<4$ & Heavily contaminated \\
\hline 5 & $4<\operatorname{lgeo}<5$ & Heavily to extremely contaminated \\
\hline 6 & Igeo $\geq 5$ & Extremely contaminated \\
\hline
\end{tabular}

Table 2: Igeo classes.

\section{Conclusions}

Soil is a vital resource for humans because its chemical and physical conditions affect agricultural production and the quality of its products that constitute one of the fundamental factors of the life cycle of the earth. Depending on their concentration in the soil, the heavy metals may determine a potential toxicity to plants and for their consumers. Their entrance in the food chain represents a geochemical risk because of their toxicity to human health, especially to the occurrence of bioaccumulation phenomena. Heavy metals can be present in the soil as a product of the weathering of the natural rocks, or because they come as part of pollution loads generated by human activities. It is very important to distinguish between the natural background values and anthropogenic inputs, and to recognize that the background values change from area to area and with the scale of the area investigated. For these reasons the geochemical monitoring of soil is important in the aim of evaluating the natural content of heavy metal in soils, related to parental materials and possible enrichment due to human activities. 


\section{References}

1. Mitchell RL, Burridge SC (1979) Trace Element in soils and crops. Phil Trans Royal Soc London B 288: 15-24.

2. Williams CH, David J (1976) The accumulation of Cadmium from Phosphorus Fertilisers and their effect on the Cadmium Content of Plants. Soil Sci 121: 86-93.

3. Dickshroon W, Van Broekhoven LW, Lampe JEM (1979) Photo toxicity of $\mathrm{Zn}, \mathrm{Ni}, \mathrm{Cd}, \mathrm{Cu}$ and $\mathrm{Cr}$ in three pasture plant species supplied with graduated amount from the soil. Nz Agric Sci 27: 241-253.

4. Underwood EJ (1971) Trace Elements in human and animal nutrition, New York. Academic Press 461-477.

5. Odigi MI, Ukrem LO, Nwankwoala HO (2011) Distribution of heavy metals in soils of Port Harcourt and its environs, Niger Delta, Nigeria. Chinese Journal of Geochemisry 30: 415-429.

6. Zhongpring Y, Wenxi Lu, Yugioo Long, Xinhau B, Qingchun Y (2011) Assessment of heavy metals contamination in urban topsoil from Changchun City, China. J Geochem Explor 108: 27-38.

7. Miragaya G (1984) Levels, Chemical Fractionation and Solubility of lead in roadside soils of Caracas Venezuela. Soil Sci 138: 147-152.

8. Ihenyen AE (1998) Heavy Metal Pollution Studies on roadside Sediments in Metropolitan Lagos Nigeria. Environmental Science MY Tokyo 6: 1-6.

9. Levy DB, Barbarick KA, Siemer EG, Sommers LE (1992) Distribution and Partitioning of Trace Metals in Contaminated Soils near Leadville, Colorado. J Enviorn Qual 21: 185-195.

10. Rowan JB, Barnes SRA, Hetherington SL, Lambers B, Parsons F (1995) Geomorphology and Pollution: The environmental impact of lead mining, Leadhills, Scotland. J Geochem Expl 52: 57-65.

11. Navarro MC, Pere-Sirvent C, Martinez-Sanchez MJ, Vidal J, Tovar PJ, et al. (2008) Abandoned mine sites as a source of contamination by heavy metals. A Case Study in a Semi arid Zone. J Geochem Explor 96: 183-193.

12. Archer FC (1980) Trace Elements in Soils in England and Wales Inorganic Pollution and Agriculture. Ministry of Agriculture Fisheries and Food Ref Book, London Her Majestys Stationery Office 184-190.

13. Hudson-Edwards KA, Macklin MG, Miller JR, Lechler PJ (2001) Sources Distribution and Storage of heavy metals in the Rio Pilcomayo, Bolivia. J Geochem Explor 72: 229-250.

14. Miller JR, Hudson-Edwards KA, Lechler PI, Preston D, Macklin MG (2004) Heavy Metal Contamination of water soil and produce within riverine communities of the Rio Pilcomayo Basin, Bolivia. Sci Total Environ 320: 189-209.

15. Taylor MP, Mackay AK, Hudson-Edwards KA, Holz E (2010) Soil Cd, Cu, $\mathrm{Pb}$ and $\mathrm{Zn}$ Contaminant, around Isa City, Queensland, Australia: Potential Sources and risks to human health. Appl Geochem 25: 841-855.

16. Wuana RA, Okieimen FE (2011) Heavy Metals in Contaminated Soils: A Review of Sources, Chemistry, Risks and Best Available Strategies for Remediation. ISRN Ecology International Scholarly Research Network 402647: 20

17. Kuo S, Heilman PE, Baker AS (1983) Distribution and forms of copper, zinc, cadmium, iron, and manganese in soils near a copper smelter. Soil Science 135: 101-109.

18. Basta NT, Ryan JA, Chaney RL (2005) Trace element chemistry in residual-treated soil: key concepts and metal bioavailability. J Environ Qual 34: 49-63.

19. Nriagu JO, Pacyna JM (1988) Quantitative assessment of worldwide contamination of air, water and soils by trace metals. Nature 333: 134-139.

20. Saur E, Juste C (1994) Enrichment of trace elements from long- range aerosol transport in sandy podzolic soils of southwest France. Water air and soil pollution 73: 235-246.

21. Steinnes E, Njastad O (1995) Enrichment of metals in the organic surface layer of natural soil: identification of contributions from different sources. Analyst 120: 1479-1483.
22. Salminen R, Gregorauskine V (2000) Considerations regarding the definition of a geochemical baseline of elements in the surficial materials in areas differing in basic geology. Applied Geochemistry 15: 647-653.

23. Feng H, Jiang H, Gao W, Weinstein MP, Zhang Q, et al. (2011) Metal contamination in sediments of the western Bohai Bay and adjacent estuaries, China. J Environ Manag 92: 1185-1197.

24. Global Investigation of Pollution in the Marine Environment (1999) Guidance on Assessment of Sediment Quality. IOCeUNEPeIMO.

25. Tessier A, Campbell PG, Bisson M (1979) Sequential extraction procedure for the speciation of particulate trace metals. Anal Chem 51: 844-851.

26. Frankowski M, Anetta ZF, Kowalski A, Siepak J (2010) Fractionation of heavy metals in bottom sediments using Tessier procedure. Environ Earth Sci 60: 1165-1178.

27. Ackerman F (1980) A procedure for correcting the grain size effect in heavy metal analyses of estuarine and coastal sediments. Environ. Technol Lett 1: 518-527.

28. Allen JRL, Rae JE (1987) Late Flandrian shoreline oscillations in the Severn Estuary: a geomorphological and stratigraphical reconnaissance. Philos Trans R Soc B Biol Sci 315: 185-230.

29. Loring DH (1990) Lithium - a new approach for the granulometrical normalization of trace metal data. Mar Chem 29: 156-168.

30. Loring DH, Naes K, Dahle S, Matishow GG, Illin G(1995) Arsenic, trace metals, and organic micro contaminants in sediments from the Pechora Sea, Russia. Mar Geol 128: 153-167.

31. Balls PW, Hull S, Miller BS, Pirie JM, Proctor W (1997) Trace metal in Scottish estuarine and coastal sediments. Mar Pollut Bull 34: 42-50.

32. Ryan JD, Windom HL (1988) A geochemical and statistical approach for assessing metal pollution in coastal sediments. Metals in Coastal Environments of Latin America. Springer Berlin Heidelberg 47-58.

33. Sinex SA, Wright DA (1988) Distribution of trace metals in the sediments and biota of Chesapake Bay. Mar Pollut Bull 19: 425-431.

34. Emmerson RHC, O'Reilly-Wiese SB, Macleod CL, Lester JN (1997) A multivariate assessment of metal distribution in intertidal sediments of the Blackwater Estuary, UK. Mar Pollut Bull 34: 960-968.

35. Lee CL, Fang MD, Hsieh MT (1998) Characterization and distribution of metals in surficial sediments in Southwestern Taiwan. Mar Pollut Bull 36: 464-471.

36. Barbieri M, Sappa G, Vitale S, Parisse B, Battistel M (2014) Soil control of trace metals concentrations in landfill: A case study of the largest landfill in Europe, Malagrotta, Rome. J Geochem Explor 143: 146-154.

37. Martin JM, Whitfield M (1983) The significance of the river input of chemical elements to the ocean. In: Wong CS, Boyle E, Brul KW, Burton JD, Goldberg ED Trace Metals in Sea Water. NATO Conference Series 9: 265-296.

38. Taylor SR, McLennan SM (1995) The geochemical evolution of the continental crust. Rev Geophys 33: 241-265.

39. Sutherland RA, Tolosa CA, Tack FMG, Verloo MG (2000) Characterization of selected element concentrations and enrichment ratios in background and anthropogenically impacted roadside areas. Arch Environ Contam Toxicol 38: 428-438.

40. Blaser P, Zimmermann S, Luster J, Shotyk W (2000) Critical examination of trace element enrichments and depletions in soils: $\mathrm{As}, \mathrm{Cr}, \mathrm{Cu}, \mathrm{Ni}, \mathrm{Pb}$, and $\mathrm{Zn}$ in Swiss forest soils. Sci Total Environ 249: 257-280.

41. Zhang J, Liu CL (2002) Riverine composition and estuarine geochemistry of particulate metals in China-weathering features, anthropogenic impact and chemical fluxes. Estuar Coast Shelf Sci 54: 1051-1070.

42. Yongming H, Peixuan D, Junji C, Posmentier ES (2006) Multivariate analysis of heavy metal contamination in urban dusts of Xi'an, Cent, China. Sci Total Environ 355: 176-186.

43. Klerks PL, Levinton JS (1989) Rapid evolution of metal resistance in a benthic oligochaete inhabiting a metal-polluted site. Biol Bull 176: 135-141.

44. Müller G (1979) Schwermetalle in den sedimenten des RheinseVeranderungen seitt 1971. Umschau 79: 778-783. 
Citation: Barbieri M (2016) The Importance of Enrichment Factor (EF) and Geoaccumulation Index (Igeo) to Evaluate the Soil Contamination. J Geol Geophys 5: 237. doi:10.4172/2381-8719.1000237

Page 4 of 4

45. Müller G (1981) Die Schwermetallbelastung der sedimente des Neckars und seiner Nebenflusse: eine Bestandsaufnahme. Chem Ztg 105: 157-164. 